\title{
NOTE
}

\section{Flow cytometric analysis of infectious pancreatic necrosis virus attachment to fish sperm}

\author{
S. Rodríguez Saint-Jean, S. I. Pérez Prieto, $M^{a}$ P. Vilas Minondo \\ Centro de Investigaciones Biológicas (Consejo Superior de Investigaciones Científicas), C/ Velazquez 144, E-28006 Madrid, Spain
}

\begin{abstract}
Male populations of rainbow trout (Oncorhynchus mykiss W.) from Spanish farms with repetitive outbreaks of infectious pancreatic necrosis (IPN) were investigated for the presence of the virus in milt samples. The analysis was done in parallel by co-cultivation of sperm cells and seminal fluid on susceptible cell cultures and by flow cytometry, using an indirect immunofluorescence assay (IFA) Pools of sperm cells, stained at the moment the milt sample arrived at the laboratory, approximately $14 \mathrm{~h}$ after collection, gave positive results for the presence of IPN virus by flow cytometry. The stained cells could be stored at $4^{\circ} \mathrm{C}$ for $48 \mathrm{~h}$ without loss of fluorescence. Aliquots of the milt samples inoculated onto cell cultures produced cytopathic effects after 3 consecutive blind passages, usually 15 to $31 \mathrm{~d}$ postinoculation. Our results confirm the attachment of IPN virus to the sperm cells and emphasize the importance of new methods, such as flow cytometer analysis, to obtain rapid and quantitative information in experimental studies of vertical virus transmission.
\end{abstract}

The infectious pancreatic necrosis virus (IPNV) is a member of the family Birnaviridae and is considered to be a nearly ubiquitous fish virus. Infection with IPNV produces high mortality rates in brook (Salvelinus fontinalis) and rainbow (Oncorhynchus mykiss) trout fingerlings. Young adults do not generally develop disease, despite virus multiplication occurring in some of their organs. Survivors of infection can remain lifelong asymptomatic carriers of the virus and serve as reservoirs of infection. The virus is known to be transmitted via eggs (Wolf 1966) even if their external surface is disinfected (Bullock et al. 1976).

Some experimental studies on the transmission of IPNV via sexual products have been done (Ahne \& Negele 1985, Dorson \& Torchy 1985) and the special importance of sperm in so-called 'vertical transmission' of fish viruses was determined by Mulcahy \& Pascho (1984), Dorson \& Torchy (1985), and Ahne et al. (1989). Hetrick (1989) remarked that milt samples have not been routinely subjected to viral analysis. However, the results of related works (Ahne 1983, Mulcahy \& Pascho 1984) suggested that this analysis would be interesting in many cases. Mulcahy et al. (1987) also reported the isolation of infectious hematopoietic necrosis virus (IHNV) from milt, but not from spleen tissue of a number of steelhead trout Salmo gairdneri. All of these reports increase interest in sampling milt for viral diagnosis, or for the study of viral transmission strategies. The present work was carried out to test the ability of flow cytometry techniques to detect the association of IPNV with sperm cells.

Methods. Indirect immunofluorescence assays (IFA), traditionally used to detect viruses in a variety of cells (Shapiro 1985), were carried out with trout sperm samples and analysed by flow cytometry, keeping in mind the results of Mulcahy \& Pascho (1984) which showed the attachment of viruses to the head membranes of spermatozoa. The automated system permits the analysis of several optical parameters including fluorescence emission, optical density and light scatter as single or multiple parameters. In addition, the measurements are performed at times on the order of a few microseconds permitting valid statistical analyses of entire cell populations.

The fish selected for study were obtained from 2 rainbow trout farms with a repetitive history of IPNV. On the first farm, a total number of 38 males were tested from a population of 800 male fish of 1.5 yr age. Milt samples from 10 survivors of a population, unequivocally established as IPNV carriers, were obtained from the second farm. Samples represented pools from 12 to 14 different fish (Farm 1) or 5 fish (Farm 2). Pools of milt were aseptically collected, maintained at $4{ }^{\circ} \mathrm{C}$ and transported to the laboratory, with the transport time being $14 \mathrm{~h}$. 
Samples were centrifuged for $10 \mathrm{~min}$ at $300 \times g$ after which the seminal fluid and cell pellets were separately recovered and tested both by flow cytometry and by the standard procedures used for the isolation of virus in cell culture followed by serological confirmation of its identity. First, aliquots of samples were prepared for indirect immunofluorescence staining and flow cytometry analysis. Milt samples from IPNVfree trout were processed in the same way and used as negative controls throughout the experiments.

Spermatozoa were serially diluted in $500 \mu \mathrm{l}$ of phosphate buffered saline (PBS) containing $1 \%$ foetal calf serum (FCS), fixed with $500 \mu \mathrm{l}$ cold formaldehyde $(3.7 \%)$ at $4{ }^{\circ} \mathrm{C}$ for $15 \mathrm{~min}$, centrifuged $(10 \mathrm{~min}$ at $300 \times g)$ and washed several times with PBS. The pelleted ceills were adied to $500 \mu \mathrm{l}$ of purified $\lg G$ anti-IPNV (1:1000 dilution) gently resuspended and incubated for $30 \mathrm{~min}$ at room temperature. After several washes with PBS-FCS, the second antibody (fluorescein isothiocyanate goat anti-rabbit immunoglobulin conjugate, FITC-GAR; Sigma) was added and incubated for $30 \mathrm{~min}$ at room temperature.

Two more washes with PBSFCS were done to remove unbound second antibody and the fluorescence of the cellular suspensions was determined by flow cytometry analysis in an EPICS CS (Coulter, Spain) equipped with an Argon ion laser, working at a wavelength of $488 \mathrm{~nm}$ and $200 \mathrm{~mW}$ output light. The following controls were included to determine the background fluorescence and the non-specific binding of antiIPNV rabbit serum to normal and IPNV carrier sperm: (a) IPNV-free sperm cells incubated only with the second antibody, (b) IPNV-free sperm cells stained with both anti-IPNV rabbit serum and FITC-GAR, (c) spermatozoa from IPNV carrier fish stained with preimmune rabbit serum and FITCGAR; (d) additionally, spermatozoa from IPNV carriers (Samples 4 and 5) were processed by IFA staining with rabbit antiserum against viral haemorrhagic septicemia virus (VHSV) to determine if any non-specific binding of rabbit antiserum to sperm membranes might have been modified by the attachment of IPNV.

Antisera to IPNV and VHSV sera were produced in rabbits (Hill et al. 1981) using purified virus produced on chinook salmon embryo (CHSE-214) cell monolayers (ATCC CRL 1681). Immunoglobulins (IgG) were purified by passage through a column of protein $A$ sepharose CL4B (Pharmacia Fine Chemicals).

Results and discussion. The results of flow cytometry analysis of samples and negative controls, stained as soon as they arrived at the laboratory, are shown in Fig. 1. Percentages of fluorescent cells were automatically recorded by the cytometer.

The stained cells in the controls were always less than $2 \%$ ranging from 1 to $1.75 \%$ (a: $1 \%$; b: 0.7 to $1.2 \%$; 1.6 to $1.7 \%$ d: $1.65 \%$ ). We used the intersection of the control and stained histograms as the marker between negative and positive zones. Samples 1, 2 and 3 (Fig. 1A) gave $18.4,13.2$ and $7.95 \%$ fluorescent cells respec-

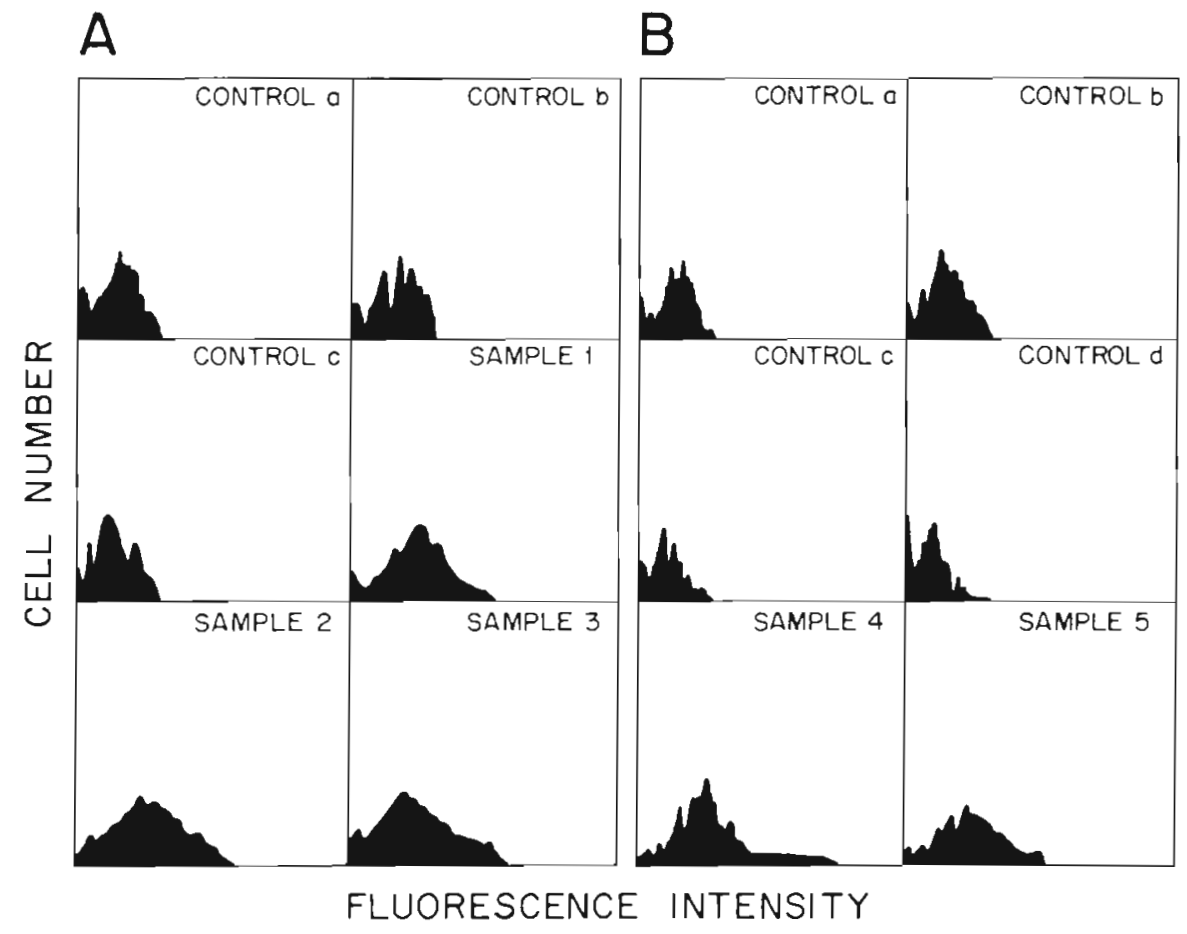

Fig. 1. Flow cytometry analysis of trout Oncorhynchus mykiss spermatozoa, stained by indirect immunofluorescence. A polyvalent anti-IPNV rabbit serum was used as specific antibody and a commercial fluorescein-conjugated anti-rabbit IgG as the second antibody. (A) and (B) represent data obtained on different occasions from 2 different farms. Samples 1, 2 and 3 were from putative IPNV-carrier fish. Samples 4 and 5 were from a fish population unequivocally established as IPNV carriers. Fluorescence background and specificity controls were as described in the text: (a) spermatozoa stained only with the second antibody (percent fluorescent cells $=1$ ); (b) uninfected spermatozoa stained with both antibodies $(0.7$ to $1.2 \%$ ); (c) infected spermatozoa stained with a pre-immune rabbit serum as first antibody (1.6 to $1.7 \%$ ); (d) infected spermatozoa stained with an anti-VHS serum as first antibody (1.65\%). In the histograms, the $y$-axis represents the relative number of cells having a particular intensity, and the $x$-axis is divided into 256 channels and represents the amount of fluorescence. Samples differing in intensity from the controls were considered as positive. 10000 cells per sample were measured 
tively. Samples 4 and 5 (Fig. 1B) gave values of 21 and $15 \%$. According to these measurements, the sperm samples from both IPNVpositive and carrier fish were identified by flow cytometry. The attachment of IPNV particles to spermatozoa from the carrier trout was verified by inoculation onto CHSE-214 cell monolayers; aliquots of milt samples (pelleted cells and seminal fluid) were used to isolate and identify the virus. Cells were counted in a Neubauer chamber and diluted in medium with $2 \%$ FCS and antibiotics (penicillin $100 \mathrm{IU}$ $\mathrm{ml}^{-1}$ and streptomycin $100 \mu \mathrm{g} \mathrm{ml}^{-1}$ ) to concentrations ranging from $1 \times 10^{3}$ to $1 \times 10^{7}$ cells $\mathrm{ml}^{-1}$. They were then assayed on CHSE-214 cells using 6 wells per dilution. Seminal fluid was employed undiluted $\left(200 \mu \mathrm{l}\right.$ well $\left.{ }^{-1}\right)$. Identification of the IPN virus was confirmed by seroneutralization after several blind passages as previously described (Rodriguez et al. 1991). Flow cytometric analyses were also performed with CHSE-214 cells that had been co-cultured with some sperm samples. The cells were stained by IFA when the first cytopathic effects (CPE) were visible. The results obtained are shown in Table 1 . The percentage of fluorescent cells increased from negligible levels ( 2 to $3 \%$ ) on the first day postinfection to $90 \%$ when cytopathic effects became visible, confirming both the results obtained before co-culture and the validity of the procedure used.

The stained cells were kept at $4{ }^{\circ} \mathrm{C}$ for $48 \mathrm{~h}$ and measured again in the flow cytometer to check the stability of the processed samples at this time. The results were identical, indicating that a delay in flow cytometry analysis is possible without loss of fluorescence.

In the present study, the spermatozoa analysed were pooled from several fish that were known to be, or not be, virus carriers. It is easy to stain a large number of milt samples for flow cytometric analyses, and to classify them as 'positive' or 'negative' according to the fluorescence emission, in only a few hours. Even individual fish could be tested. Because IPN is at the moment the only virus that causes important economic losses in Spanish trout farms, some experiments of this type are in progress, with the farmers' cooperation, to attempt to obtain IPN-free broodstocks which, once found, will be periodically tested for virus. Also, in vitro studies on virus-sperm interactions, providing a rapid and quantitative determination of virion binding to the sperm cells, would be useful in cytotoxic determinations, virucidal assays and in the determination of inhibitory effects of compounds on virion attachment.
Table 1. Results of co-culturing sperm cells from IPNV-carrier trout Oncorhynchus mykiss (samples 1 to 5) and IPNV-free trout (control) on CHSE-214 cell monolayers. CPE: cytopathic effects

\begin{tabular}{|c|c|c|c|c|}
\hline Samples & $\begin{array}{l}\text { Passage } \\
\text { number }\end{array}$ & $\begin{array}{l}\text { Days after } \\
\text { first inocu- } \\
\text { lation }\end{array}$ & CPE & $\begin{array}{l}\text { Percent of fluorescent } \\
\text { cells (measured by } \\
\text { flow cytometry) }\end{array}$ \\
\hline \multirow[t]{4}{*}{1} & - & 0 & & 18.4 (inoculum) \\
\hline & 1 & 7 & $(-)$ & 3.0 \\
\hline & 2 & 11 & $(+)$ & 66.89 \\
\hline & 3 & 15 & $(+)$ & 96.14 \\
\hline \multirow[t]{5}{*}{2} & - & 0 & & 13.2 (inoculum) \\
\hline & 1 & 7 & $(-)$ & 2.0 \\
\hline & 2 & 14 & $(-)$ & 2.0 \\
\hline & 3 & 18 & $(-)$ & 2.0 \\
\hline & 4 & 28 & $(+)$ & 92.89 \\
\hline \multirow[t]{6}{*}{3} & - & 0 & & 7.95 (inoculum) \\
\hline & 1 & 7 & $(-)$ & 1.8 \\
\hline & 2 & 14 & $(-)$ & 1.8 \\
\hline & 3 & 21 & $(-)$ & 1.8 \\
\hline & 4 & 28 & $(-)$ & 1.8 \\
\hline & 5 & 32 & $(+)$ & 81.55 \\
\hline \multirow[t]{3}{*}{4} & - & 0 & & 21.0 (inoculum) \\
\hline & 1 & 7 & $(-)$ & - \\
\hline & 2 & 15 & $(+)$ & 80.29 \\
\hline \multirow[t]{3}{*}{5} & - & 0 & & 15.0 (inoculum) \\
\hline & 1 & 7 & $(-)$ & - \\
\hline & 2 & 15 & $(+)$ & 76.73 \\
\hline \multirow[t]{3}{*}{ Control } & - & 0 & & 0.2 to 1.7 \\
\hline & 1 & 7 & $(-)$ & \\
\hline & 4 & 28 & $(-)$ & 0.2 to 1.5 \\
\hline
\end{tabular}

Acknowledgements. This work was supported by the Centro para el Desarrollo Tecnológico Industrial (PO35/88) and by grant MAR-91-0365 from the Comision Interministerial de Ciencia y Tecnología. We thank NUTRISA S.A. and SMS Zootecnia for their cooperation in providing the fish samples. We also thank Dr Alberto Marquet for comments and critical review of the manuscript.

\section{LITERATURE CITED}

Ahne, W. (1983). Presence of IPNV in the seminal fluid of rainbow trout Salmo gairdnen. J. Fish Dis. 6: 377-378

Abne, W., Negele, R. D. (1985). Studies on the transmission of IPNV via eyed eggs and sexual products of salmonid fish. In: Ellis, A. E. (ed.) Fish and shellfish pathology. Academic Press, London, p. 260-269

Ahne, W., Kelly, R. K., Schlotfeldt, H. J. (1989). Factors affecting the transmission and outbreak of infectious pancreatic necrosis (IPN). In: Lillelund, K., Rosenthal, H. (eds.) Fish health protection strategies. Federal Ministry for Research and Technology, Bonn, p. 19-71

Bullock, G. L., Rucker, R. R., Amend, D., Wolf, K., Stuckey, H. M. (1976). Infectious pancreatic necrosis transmission with iodine-treated and non-treated eggs of brook trout ( $\mathrm{Sa}$ velinus fontinalis). J. Fish. Res. Bd Can. 33(5): 1197-1198

Dorson, M., Torchy, C. (1985). Experimental transmission of infectious pancreatic necrosis virus via the sexual prod- 
ucts. In: Ellis, A. E. (ed.) Fish and shellfish pathology. Academic Press, London, p. 251-260

Hetrick, F. M. (1989). Fish viruses. In: Austin, B., Austin, D. A. (eds.) Methods for the microbiological examination of fish and shellfish. John Wiley and Sons, Chichester, p. $216-239$

Hill, B. J., Williams, R. F., Finlay, J. (1981). Preparation of antisera against fish virus disease agents. In: Hennessen, W. (ed.) Developments in biological standardization 49 . S. Karger, Basel, p. 209-218

Mulcahy, D., Pascho, R. (1984). Adsorption to fish sperm of vertically transmitted fish viruses. Science 225: 333-335

Responsible Subject Editor: F. M. Hetrick, College Park, Maryland, USA
Mulcahy, D., Pascho, R., Batts, W. (1987). Testing of male sockeye salmon (Oncorhynchus nerka) and steelhead trout (Salmo gairdneri) for infectious hematopoietic necrosis virus, Citi. J. Fish. Aquat. Sci. 44: 10751078

Rodriguez, S., Vilas, M. P., Palacios, M. A., Pérez, S. (1991). Detection of infectious pancreatic necrosis in a carrier population of rainbow trout $O$. mykiss (Walbaum), by flow cytometry. J. Fish Dis. 14: 545-553

Shapiro, H. (1985). Flow cytometry applications: an overview. In: Liss, A. R. (ed.) Practical flow cytometry. Alan R. Liss, Inc., New York, p. 159-170

Wolf, K. (1966). The fish viruses. Adv. Virus Res. 12: 35-101

Manuscript first received: August 20, 1992

Revised version accepted: December 9, 1992 